\title{
KONSTRUKSI VEKTOR EKSPRESI GEN HORMON PERTUMBUHAN LELE DUMBO (Clarias sp.) UNTUK PRODUKSI IKAN LELE LOKAL (Clarias batrachus) TRANSGENIK
}

\author{
Ibnu Dwi Buwono"\#, Nono Carsono"), Yuniar Mulyani"), dan M. Untung Kurnia") \\ ") Fakultas Perikanan dan Ilmu Kelautan, Universitas Padjadjaran \\ Fakultas Pertanian, Universitas Padjadjaran
}

(Naskah diterima: 11 April 2014; Revisi final: 26 Februari 2015; Disetujui publikasi: 11 Maret 2015)

\begin{abstract}
ABSTRAK
Penelitian ini bertujuan untuk memperoleh konstruksi vektor ekspresi (pTarget) rekombinan yang mengandung sisipan gen hormon pertumbuhan ikan lele dumbo (Clarias sp.) dan promoter $\beta$-aktin ikan lele lokal (C. batrachus) dalam upaya pembuatan ikan lele lokal transgenik. Promoter $\beta$-aktin lele lokal (pCbBA) telah berhasil diisolasi dari hipofisa ikan tersebut dengan ukuran sekitar 1,7 kbp; dan memiliki elemen transkripsi CAAT box, TATA box, GC box, motif CArG, dan TGACG berdasar analisis program TF Bind. Penggantian promoter CMV (cytomegalovirus) yang terkandung dalam vektor ekspresi pTarget menggunakan dua enzim restriksi Sgf-I dan I-Ppo I, menghasilkan fragmen DNA berukuran 6.083 bp (pTarget-GH lele dumbo) sebagai produk digesti. Fragmen pTarget-GH lele dumbo yang diligasi dengan promoter $\beta$-aktin lele lokal membentuk konstruksi pTarget-pCbBA-GH lele dumbo $(7.783 \mathrm{bp})$ sebagai vektor ekspresi ikan lele lokal transgenik.
\end{abstract}

KATA KUNCI: vektor ekspresi, hormon pertumbuhan, lele dumbo, lele lokal transgenik

ABSTRACT: Construct of growth hormone gene expression vector of African catfish (Clarias sp.) to produce transgenic walking catfish (Clarias batrachus). By: Ibnu Dwi Buwono, Nono Carsono, Yuniar Mulyani, and M. Untung Kurnia

\begin{abstract}
This study aims to obtain an expression vector construct (pTarget) containing recombinant growth hormone gene insertion of African catfish (Clarias sp.) and $\beta$-actin promoter derived from walking catfish (Clarias batrachus) in order to produce transgenic local catfish. $\beta$-actin promoter of walking catfish ( $\mathrm{pCbBA}$ ) have been isolated from the pituitary of the fish with a size of about $1.7 \mathrm{kbp}$, and has a transcription element: CAAT box, TATA box, GC box, CArG, and TGACG motif based on analysis result of TF Bind program. Replacement of CMV (cytomegalovirus) promoter contained in the expression vector pTarget using restriction enzymes Sgf-I and I-Ppo I, obtained a product of digestion with the fragment size of 6,083 bp (pTarget-GH African catfish). pTarget-GH fragments were ligated with the African catfish $\beta$-actin promoter to arrange a construct of pTarget-pCbBA-African catfish $G H(7,783 \mathrm{bp})$ as transgenic walking catfish expression vector.
\end{abstract}

KEYWORDS: $\quad$ expression vectors, growth hormone, African catfish, transgenic walking catfish

\section{PENDAHULUAN}

Aspek penting yang menjadi kunci keberhasilan budidaya ikan (termasuk produksi induk dan benih unggul) adalah penguasaan bioteknologi pembenihan (rekayasa gen dan breeding), pakan, proteksi penyakit, dan manajemen (Chen et al., 1997). Rekayasa gen yang dimanfaatkan dalam budidaya ikan ditujukan untuk memperbaiki genetik pertumbuhan, dalam hal ini me-

\# Korespondensi: Fakultas Perikanan dan Ilmu Kelautan, Universitas Padjadjaran. Jl. Raya Bandung Sumedang KM 21, Jatinangor 40600, Indonesia. Tel.: + (022) 7797763

E-mail: ibnudw1@yahoo.com ningkatkan ekspresi fenotipe pertumbuhan sebagai upaya meningkatkan produksi hasil budidaya.

Produksi ikan lele lokal (Clarias batrachus) unggul melalui program seleksi, memerlukan waktu lebih lama, lambatnya pewarisan gen terseleksi pada keturunan dari ikan yang diseleksi. Hal ini menjadikan pembudidaya ikan lele lokal beralih ke budidaya ikan lele dumbo (Clarias sp.), oleh karena sifat pertumbuhan lele lokal yang lambat walaupun rasa dagingnya lebih enak dibandingkan lele dumbo.

Selama dekade terakhir, spermatozoa pada ikan telah banyak diteliti peranannya dan dapat bertindak 
sebagai vektor untuk transfer gen asing dalam teknologi ikan transgenik yang dikenal sebagai transfer gen yang diperantarai sperma $($ SMGT $=$ Sperm Mediated Gene Transfer) (Collares et al., 2010). Secara alami, hewan akuatik memproduksi sejumlah besar sel-sel sperma yang sangat menguntungkan bagi aplikasi teknik SMGT tersebut. Rekayasa genetika, khususnya teknologi rekombinan DNA mulai banyak diaplikasikan di bidang pembenihan ikan guna meningkatkan pertumbuhan melalui penyisipan gen hormon pertumbuhan tersebut ke dalam DNA genom telur atau sperma ikan.

Sejauh ini telah banyak usaha dilakukan untuk mengatur hormon-hormon pada ikan atau dengan rekombinasi hormon dari mamalia dalam plasmid yang diintegrasikan pada genom ikan sehingga dapat memproduksi hormon dalam jumlah banyak, meningkatkan pertumbuhan, dan efisiensi pakan (Chen \& Powers, 1990).

Pemberian hormon pertumbuhan alami mamalia ke dalam pakan ikan maupun dengan cara perendaman hormon tersebut ke dalam telur-telur ikan dipandang tidak efisien, karena setiap akan memproduksi ikan unggul, pekerjaan harus dilakukan berulang-ulang untuk maksud tersebut. Sebaliknya dengan mengintegrasikan gen asing yang mengekspresikan hormon pertumbuhan ke dalam inti sel ikan dan kemudian dibesarkan sampai induk lebih efisien untuk mewariskan sifat pertumbuhan pada keturunannya.

Perkembangan metode transfer gen secara massal sangat penting, mengingat tingginya jumlah telur ikan dan fertilisasi eksternal. Teknologi DNA rekombinan pada ikan dan sekuen-sekuen regulatorik (sekuen promoter) telah dapat dikloning dan potensial dimanfaatkan untuk pembuatan konstruksi vektor ekspresi yang mengandung gen-gen ikan yang bernilai ekonomis (Muller et al., 1993; Dewi et al., 2010a). Pengujian sekuen-sekuen regulatorik yang dikloning (termasuk sekuen promoter), secara in vivo fungsional untuk mempermudah ekspresi transgen yang disisipkan melalui sperma untuk produksi massal ikan transgenik (Alimuddin et al., 2007; Sin et al., 1997). Produksi transgen secara stabil memerlukan waktu dari generasi ke generasi, mengingat tidak $100 \%$ transformasi gen ikan melalui elektroporasi sperma berhasil diwariskan ke telur ikan.

Penggunaan promoter $\beta$-aktin yellow catfish (Ge et al., 2012) ke dalam konstruksi vektor ekspresi rekombinan yang mengandung gen hormon pertumbuhan (Growth Hormone/GH) lele dumbo yang ditransfer ke sperma ikan lele lokal (Clarias batrachus) melalui teknik SMGT ini diharapkan dapat meningkatkan ekspresi transgen tersebut dalam DNA genom larva lele, mengingat promoter $\beta$-aktin Clarias batrachus dapat dikenali oleh elemen transkripsi dan ekspresi dalam DNA genom ikan lele lokal.

Berlandaskan uraian di atas, bahwa penelitian SMGT (mengandung sisipan gen GH lele dumbo) pada ikan lele lokal (Clarias batrachus) masih terbatas diterapkan, maka diperlukan penelitian perakitan konstruksi vektor ekspresi GH lele dumbo dalam upaya pembuatan ikan lele lokal transgenik.

Target penelitian yang ingin dicapai adalah pembuatan konstruksi vektor ekspresi gen hormon pertumbuhan ikan lele dumbo yang fungsional dapat terintegrasi dalam DNA genom sperma ikan lele lokal untuk tujuan produksi ikan lele lokal transgenik. Tujuan umum dilakukan penelitian tersebut untuk memperbaiki sifat pertumbuhan lele lokal dari sifat pertumbuhan asalnya yang lebih meningkat dengan mentransfer $\mathrm{GH}$ lele dumbo ke dalam genom sperma lele lokal.

Hasil yang diharapkan dari penelitian adalah memberikan kontribusi kepada pembudidaya ikan air tawar untuk membudidayakan kembali lele lokal yang pertumbuhannya sama dengan lele dumbo sehingga produksi meningkat dan sebagai upaya penyediaan pangan nasional, serta stabilitas perikanan budidaya berkelanjutan.

\section{BAHAN DAN METODE}

Sampel yang digunakan untuk melipatgandakan fragmen DNA hormon pertumbuhan ikan lele dumbo dan DNA promoter $\beta$-aktin ikan lele lokal berasal dari hipofisa ikan tersebut. Isolasi RNA hipofisa dari ikan lele dumbo dilakukan menggunakan high pure RNA tissue kit, primer ORF-Cg-GH-F (5'-ATGGCTCGAGTTT TGGTGCTGCT-3') dan ORF-Cg-GH-R (5'-CTACAGAGTG CAGTTGGAATCCAGGG-3') (Zhang et al., 2009); serta onestep RT-PCR kit (Qiagen) untuk mengamplifikasi gen hormon pertumbuhan ikan lele dumbo. Primer pBA-Cs-F (5'-GTGWGTGACGCYGGACCAAATC-3') dan pBA-Cs-R (5'-CCATRTCRTCCCAGTTGGTSACAAT-3') (Ge et al., 2012) digunakan untuk mengamplifikasi promoter $\beta$-aktin ikan lele lokal. Vektor pGEM-T digunakan untuk kloning gen hormon pertumbuhan ikan lele dumbo dan promoter $\beta$-aktin ikan lele lokal, pTARGET $^{\mathrm{TM}}$ digunakan sebagai vektor ekspresi gen hormon pertumbuhan ikan lele dumbo dan kit plasmid genaid untuk mengisolasi promoter-promoter $\beta$ aktin ikan lele lokal dan gen hormon pertumbuhan ikan lele dumbo yang dikloning dalam bakteri Esherichia coli.

\section{Perakitan Konstruksi Vektor Ekspresi pTARGET- Promoter CMV dan pTARGET-Promoter $C b B A$}

Transgen yang digunakan untuk produksi ikan lele lokal transgenik terbagi atas dua macam kons- 
truksi vektor ekspresi yaitu: (1) pTARGET-CMV-CgGH dan (2) pTARGET-pCbBA-CgGH. Konstruksi pTARGETCMV-GH lele dumbo yang dirancang disajikan pada Gambar 1 dan konstruksi pTARGET-CbBA-GH lele dumbo disajikan pada Gambar 2, yang mengganti promoter CMV dengan promoter $\beta$-aktin Clarias batrachus (pCbBA).

Insersi promoter $\beta$-aktin Clarias batrachus ( $\mathrm{pCbBA}$ ) ke pTARGET, dengan cara men-digesti vektor tersebut dengan enzim restriksi $S g f$ I dan I-Ppo I, kemudian disambungkan (diligasi) dengan sekuen promoter pCbBA. Sebelum dilakukan penyisipan promoter pCbBA, sekuen promoter tersebut dianalisis menggunakan program TF Bind (Transcription Factor Binding) untuk memastikan sekuen promoter tersebut telah memiliki sekuen fungsional yaitu: CAAT box, TATA box, dan motif CArG yang penting untuk mendorong transkripsi gen GH lele dumbo yang diinsersikan dalam konstruksi vektor pTARGET ${ }^{\mathrm{TM}}$-CbBA-GH lele dumbo tersebut. Promoter CMV pada vektor pTARGET ${ }^{\mathrm{TM}}$ diganti (replacement) dengan promoter p $C b B A$, dengan memotong (digesti) sekuen CMV menggunakan dua enzim restriksi ( $S g f$-I dan I-Ppo I) pada pTARGET untuk membuang sekuen CMV, kemudian menyisipkan promoter pCbBA tersebut ke dalam vektor.

Proses digesti vektor dilakukan dengan melarutkan $5 \mu \mathrm{L}$ pTARGET; $2 \mu \mathrm{L}$ 10x buffer RE; 0,5 $\mu \mathrm{L}$ BSA; 1 $\mu \mathrm{L}$ enzim Sgf-I; $1 \mu \mathrm{L}$ enzim I-Ppo I; dan 11,5 $\mu \mathrm{L}$ SDW. Reaksi digesti diinkubasi selama tiga jam pada suhu $37^{\circ} \mathrm{C}$.

Proses ligasi dilakukan dengan mencampurkan 3 $\mu \mathrm{L}$ promoter $\mathrm{pCbBA} ; 1 \mu \mathrm{L}$ T4 DNA ligase $10 \mathrm{x} ; 1 \mu \mathrm{L}$ enzim T4 DNA ligase; $4 \mu \mathrm{L}$ SDW; dan $1 \mu \mathrm{L}$ pTARGET yang telah dipotong dengan enzim Sgf-I dan I-Ppo I. Inkubasi dilakukan selama dua jam pada suhu ruang

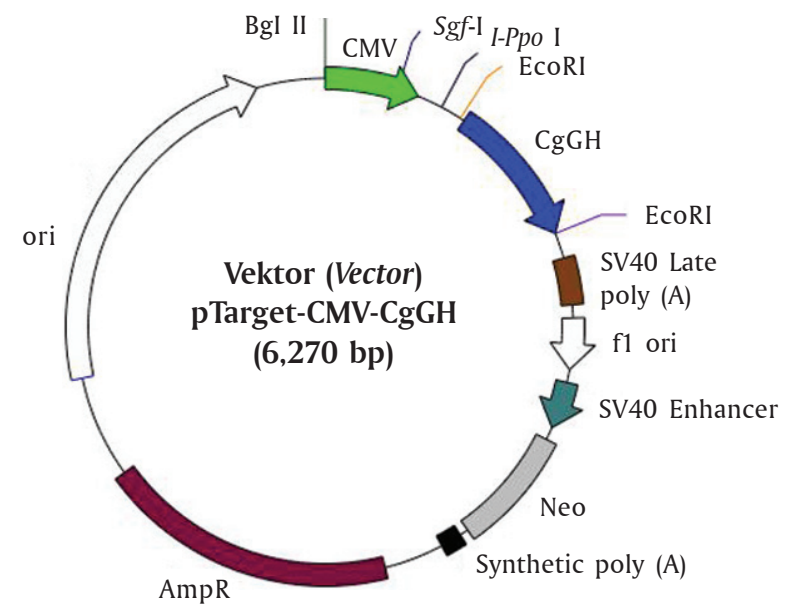

Gambar 1. Konstruksi pTARGET ${ }^{\mathrm{TM}}$-CMV-CgGH (6.270 bp)

Figure 1. Construction pTARGET ${ }^{T M}-C M V-C g G H(6,270$ bp) dan dilanjutkan semalaman pada suhu $4^{\circ} \mathrm{C}$. Peta konstruksi pTARGET-pCbBA-GH lele dumbo disajikan pada Gambar 2.

\section{Transformasi Vektor Ekspresi Rekombinan (pTARGET $^{\mathrm{TM}}$-gen GH Lele Dumbo) pada Sel Kompeten E. coli JM 109}

Setelah pembuatan vektor ekspresi rekombinan, pengerjaan selanjutnya mengkloning vektor tersebut ke dalam sel kompeten, untuk memperoleh kopi-kopi hormon pertumbuhan lele dumbo secara in vivo. Sebelum dilakukan proses kloning gen GH lele dumbo, dibuat terlebih dahulu medium tumbuh sel kompeten $E$. coli. Medium tumbuh yang dibutuhkan ada dua macam, yaitu: (1) medium untuk kultur cair sel kompeten, terbuat dari $40 \mathrm{~g}$ Circle grow broth yang dicampur dengan 1 liter milliq $\mathrm{H}_{2} \mathrm{O}$ steril, dan (2) medium kultur padat (solid) yang terbuat dari campuran 25 g Luria Bertani (LB) broth (LB broth) dengan $15 \mathrm{~g}$ Bacto agar dalam 1 liter milliq $\mathrm{H}_{2} \mathrm{O}$ steril. Medium kultur padat tersebut kemudian di-plating ke dalam cawan petri sesuai dengan jumlah kebutuhan. Sedangkan untuk medium kultur cair dilakukan di dalam tabung reaksi dengan jumlah volume medium $5 \mathrm{~mL}$ dan ditambahkan ampicillin sesuai kebutuhan.

Untuk meningkatkan pertumbuhan sel, diperlukan medium SOC, serta untuk menginduksi koloni agar tumbuh dalam kultur padat ditambahkan IPTG dan X-gal. Seleksi koloni putih (hanya mengandung insert ORF-Cg-GH) dilakukan dengan penambahan antibiotik ampicillin pada medium kultur tersebut.

Secara garis besar, protokol teknik kloning dan transformasi produk ligasi dalam vektor kloning dan vektor ekspresi yang ditransformasikan ke dalam sel kompeten E. coli JM 109 dipaparkan sebagai berikut;

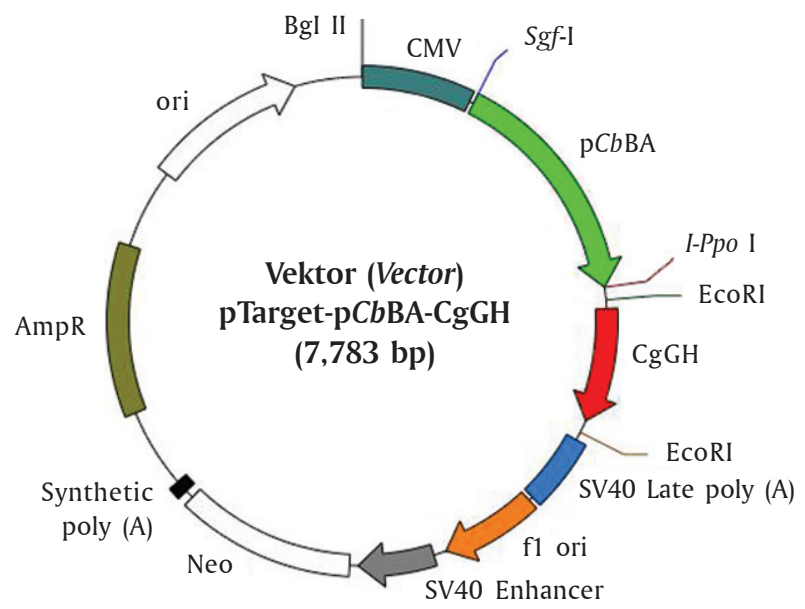

Gambar 2. Konstruksi vektor pTARGET ${ }^{\mathrm{TM}}-\mathrm{pC}$ CbACgGH (7.783 bp)

Figure 2. Vector construction pTARGET ${ }^{T M}$ - $p C b B A-C g G H$ $(7,783 \mathrm{bp})$ 
dipersiapkan dua plate LB/ampicillin/IPTG/X-gal untuk setiap reaksi ligasi. Tahap selanjutnya dilakukan sentrifugasi tube-tube yang mengandung reaksi ligasi untuk mengumpulkan kandungannya pada dasar tube, kemudian ditambahkan $2 \mu \mathrm{L}$ setiap reaksi ligasi ke mikrotube $1,5 \mathrm{~mL}$ steril on-ice. Segera diambil microtubemicrotube beku sel kompeten JM 109 dari penyimpanan $-80^{\circ} \mathrm{C}$ dan ditempatkan dalam stryrofoam berisi timbunan es curai hingga mencair (kira-kira lima menit). Sel-sel dicampurkan dengan teknik flicking (menjentik-jentikan tube dengan jari tangan). Dengan ekstra hati-hati, $50 \mu \mathrm{L}$ sel kompeten JM 109 ditransfer ke dalam setiap tube berisi campuran reaksi ligasi yang telah dipersiapkan sebelumnya. Secara perlahan-lahan, menjentik-jentikan tube untuk mencampur dan kemudian segera ditempatkan on ice dalam styrofoam selama 20 menit.

Sebelum transformasi, dipersiapkan waterbath (dengan suhu stabil $42^{\circ} \mathrm{C}$ ), dan segera dilakukan heat shock (kejutan panas) sel-sel kompeten yang telah dicampur reaksi ligasi selama 90 detik (tidak boleh digoyang-goyang). Segera dikembalikan tube-tube ke styrofoam berisi es curai selama dua menit. Proses dilanjutkan dengan menambahkan $950 \mu \mathrm{L}$ medium SOC pada suhu ruang ke dalam sel-sel kompeten tersebut untuk masing tube-tube yang telah dilabel. Tahap akhir dilakukan inkubasi selama dua jam pada suhu $37^{\circ} \mathrm{C}$ dengan shaking (penggoyangan) kecepatan $125 \mathrm{rpm}$ menggunakan shaking waterbath.

\section{Amplifikasi Sekuen Promoter $\beta$-Aktin Lele Lokal}

DNA genom ikan lele lokal digunakan sebagai template untuk mengkopi sekuen promoter $\beta$-aktin lele tersebut menggunakan primer pBA-Cs-F (5'-GTGWG TGACGCYGGACCAATC-3') dan pBA-Cs-R (5'-CCATRT CRTCCCAGTTGGTSACAAT-3') yang dirujuk dari Ge et al. (2012).

Campuran reaksi PCR (polymerase chain reaction) dalam volume akhir $25 \mu \mathrm{L}$ yang mengandung $12,5 \mu \mathrm{L}$ fast start PCR master mix (Roche); 1,5 $\mu \mathrm{L}$ pBA-Cs-F (10 $\mu \mathrm{M}) ; 1,5 \mu \mathrm{L}$ pBA-Cs-R $(10 \mu \mathrm{M}) ; 2,5 \mu \mathrm{L}$ DNA genom lele; dan $7 \mu \mathrm{L}$ nuclease free water. Penggandaan sekuen promoter tersebut dilakukan dengan pengaturan program PCR : pra-denaturasi $95^{\circ} \mathrm{C}$ selama lima menit; denaturasi $94^{\circ} \mathrm{C}$ selama satu menit; annealing $62^{\circ} \mathrm{C}$ selama 45 detik; ekstensi $72^{\circ} \mathrm{C}$ selama dua menit dengan jumlah siklus sebanyak 30 kali replikasi dan ekstensi akhir $72^{\circ} \mathrm{C}$ selama sepuluh menit.

Pengerjaan dilanjutkan dengan elektroforesis produk PCR di atas dalam gel agarose 1\%. Kondisi elektroforesis sebagai berikut: tegangan listrik 75 volt, waktu 90 menit, perendaman dalam ethidium bromide selama 20 menit, dan pencucian dalam akuades steril selama 15 menit.

\section{Sekuensing Promoter $\beta$-Aktin Ikan Lele Lokal}

Analisis sekuen DNA promoter $\beta$-aktin lele lokal dilakukan untuk verifikasi keberadaan elemen-elemen transkripsi yang terkandung dalam sekuen tersebut, seperti halnya yang telah dilakukan untuk analisis promoter grass carp (Li et al., 2007). Sekuensing dilakukan di PT Genetika Science Indonesia ( $1^{\text {st }}$ Base Singapore) dan sekuen tersebut diverifikasi dengan menyejajarkan (alignment) elemen transkripsi sekuen promoter $\beta$-aktin lele lokal (C. batrachus) dengan elemen transkripsi sekuen promoter $\beta$-aktin Indian catfish (Heteropneustes fossilis) dan yellow catfish (Pelteobagrus fulvidraco) yang terdapat di Bank Gen dengan program GENETYX versi 7.

\section{HASIL DAN BAHASAN}

\section{Amplifikasi Fragmen Promoter $\beta$-Aktin Lele Lo- kal}

Amplifikasi sekuen promoter $\beta$-aktin lele lokal ( $\mathrm{pCbBA}$ ) dilakukan menggunakan primer pBA-Cs-F dan pBA-Cs-R merujuk hasil penelitian Ge et al. (2012). Hasil amplikon (produk PCR) yang telah diperoleh sekitar $1.700 \mathrm{bp}$, dan dilanjutkan dengan mengirimkan sampel produk PCR ke jasa service sekuensing $1^{\text {st }}$ Base Singapore melalui PT Genetika Science Indonesia, Jakarta untuk meyakinkan bahwa sekuen tersebut merupakan sekuen promoter (menggunakan program Promoter Scan). Gambar 3 merupakan hasil amplifikasi sekuen promoter $\mathrm{p} C b \mathrm{BA}$, dengan ukuran fragmen sekitar $1.700 \mathrm{bp}$.

Ukuran fragmen promoter $\beta$-aktin lele lokal ini tidak jauh berbeda dengan ukuran fragmen promoter $\beta$-aktin yellow catfish yang telah diteliti Ge et al. (2012) sebesar $1.617 \mathrm{bp}$. Amplifikasi pada produk PCR promoter $\beta$-aktin lele lokal tersebut menandakan, fragmen yang terkopi oleh primer pBA-Cs-F dan pBA-Cs-R diprediksikan merupakan sekuen promoter $\beta$-aktin lele lokal.

Verifikasi hasil sekuensing produk PCR pada Gambar 3 menggunakan software Promoter Scan versi 1.7 diperlukan untuk menentukan apakah sekuen tersebut mengandung CAAT box, TATA box, dan motif CArG yang diketahui penting dalam aktivitas promoter $\beta$ aktin.

Ketiga elemen transkripsi (CAAT box, motif $C A r G$, TATA box) pada sekuen promoter $\beta$-aktin ikan lele lokal $\beta$-aktin ikan lele lokal terdeteksi secara manual. Faktor transkripsi (TFIID) yang terikat dengan elemen TATA box untuk menginisiasi transkripsi terdeteksi dengan program ProScan versi 1.7 secara on line (Gambar 4). Lokasi elemen CAAT box terdapat pada nukleotida (nt.) 22-29, motif $C A r G$ pada nt. 615-623, elemen TATA box pada nt. 49-54, dan nt. 296-302 untuk 


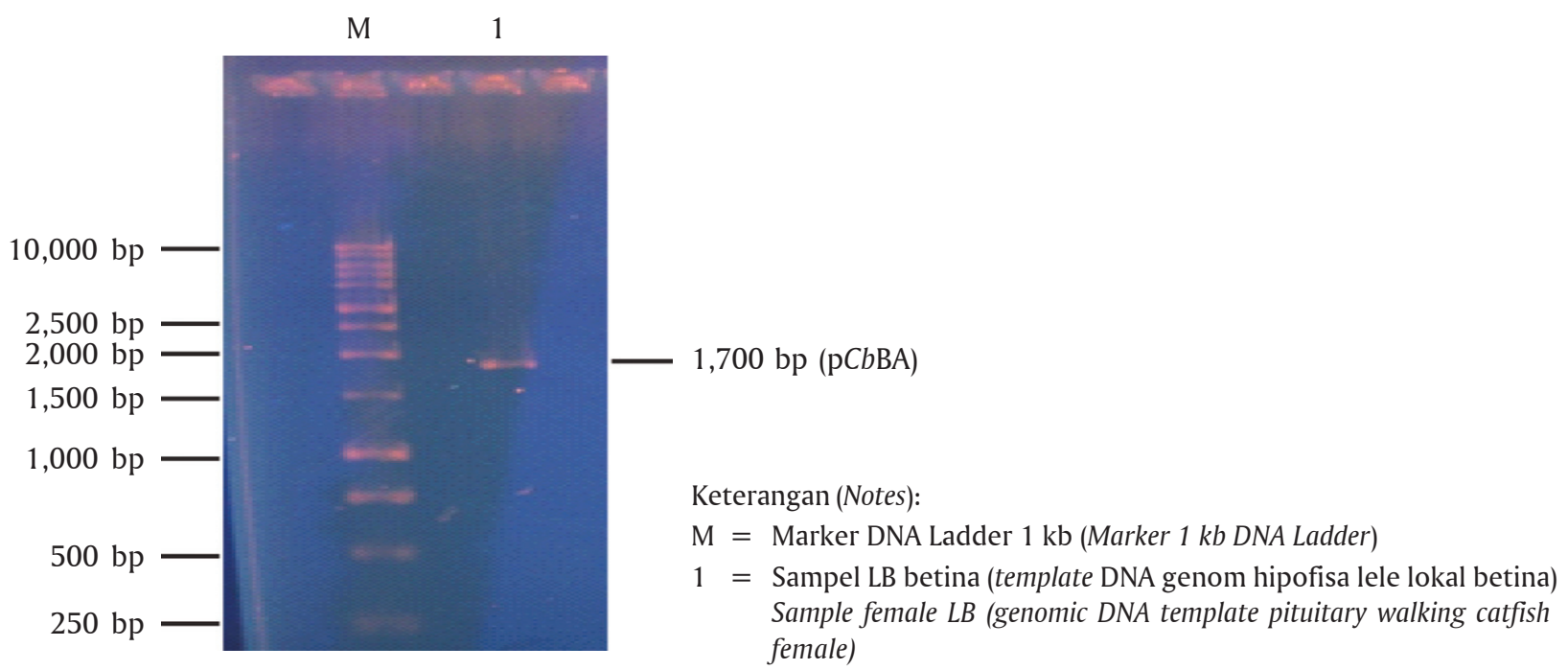

Gambar 3. Fragmen pCbBA (1.700 bp)

Figure 3. Fragment $p C b B A(1,700 \mathrm{bp})$

1 TANGNNNNTCTTCCGAAAAGGGTCCATTTTAGACGGCCATGTGGAGCGTA

51 TAAAACCAGGCGCCCAGACTCCCACTTCACTTTGAGCTCCTCCACACGCA

101 GCTAGTGCGGAATATCATCTGCCCAACCAAATTTATTTTTTCTTAAGCCG

151 ACAACCCCCAAATCTTAAGGTAAGTTTTTTTCCCCCTTTCCTCCTGGTAT

201 TGTTATTACTGTTAGCAATAGTAATTGCAGTAACAATAGTAACATTGCTA

251 TTTATGTATGCAAGGGTTTTAATTGTAAAAACTATATATATATTTTTATA

301 AATTAATGAATGACTGCAAAAAGAACAATACGTTTTCCCTTTATCATGCA

351 GCGATATTAAACTAGACAGGAATTATTTTTGTAAATTTTTACCTCAGGTT

401 TTTTтTтTTTTTTCCCTGGGGgCTAAAAGCCCCGTAAAACGGCGGGGAGG

451 GGGGGGTTTTTTTTTATTTCTATAAATGAAAAAACCGTTTTTTGCCCTGA

501 TTATTAAAAAGCGGAGGAAGACCCGTATTTGTCGACGATAATCACAAAAA

551 AAGCGGGGGCGGGGGGCCTCCCCCGTTTTTTCCACCTCCCCCCCGGAGAG

601 GGTAGGATTTCACCCAAATTGGGACAACGAGACCCCTGGGGTAATTCGCT

651 GCCTACCCCTGGGCACTTGAAAAGGGGGGCCCAGTCGTGCTTAAGGCTGT

701 CAAGCCAAGAAGGCTCCCCCATTTTTTTCTCGCTAGGGGGGGGGGCCAGA

751 AАAАATAАTATATTTTTTTTATTTTATACCTACTTCCTCACAACTGTACA

801 AAAAAAAGCCACTGACGAGCTCTTGTTATTACAACACCCAGAGATATTGT

851 CCGTCTTATAATTTTTTTTTCTAAAGGCGCCACAAAGCGGACCACACACT

901 TAAATCATAGTTAAGTAAGGCCGCCTTGTTGGTGAGCAAGTATACAGGAC

951 CGGGAAGTAGAGATAGAATGAGTTGATAAAATTAAAATATAAATTTGTTC

1001 AGNNTGAACGGAGGCCTGCCCGGGCTCTGCAGATN

\author{
Keterangan (Notes): \\ TATAAA $=$ Sekuen core promoter \\ (Promoter core sequence) \\ CAAT $=$ Sekuen enhancer (Enhancer \\ sequence) \\ CCAAAT $=$ CCAAT box \\ CAAATTGG $=$ Motif CArGG $(C A r G G$ \\ motive)
}

Gambar 4. Motif CArG, CAAT box dan TATA box pada sekuen promoter $\beta$-aktin lele Lokal (arah forward) Figure 4. The motive CArG, CAAT box and TATA box of the promoter sequence of $\beta$-actin walking catfish (forward direction)

promoter $\beta$-aktin ikan lele lokal (C. batrachus), sementara pada Indian catfish (Heteropneustes fossilis, no. aksesi AY 531754), terletak pada nt. 343-347 (CAAT box), elemen $C A r G$ pada nt. 372-381, serta nt. 345-350 (elemen TATA box). Elemen transkripsi penting promoter $\beta$-aktin semua vertebrata direpresentasikan oleh CAAT box, motif CArG, dan TATA box yang terkandung dalam sekuen promoter tersebut (Hew \& Fletcher, 2001). CAAT box merupakan enhancer yang diperlukan untuk meningkatkan level transkripsi, motif-motif $C A r G$ terlibat dalam pengaturan transkripsi basal dan elemen TATA box berperan dalam pengaturan transkripsi gen fungsional yang terletak pada proxi- mal promoter (Aranburu et al., 2006; Santoro \& Walsh, 1991).

Elemen lain yang penting dalam penentuan situs pengikatan RNA polimerase II ketika transkripsi akan berlangsung adalah GC box (sekuen GGGCGGG) dan motif TGACG yang berperan sebagai perantara faktor hormon pertumbuhan dari hipofisa (Argenton et al., 1996) pada sekuen promoter $\beta$-aktin catfish. Hasil penjajaran elemen-elemen transkripsi antara promoter $\beta$-aktin ikan lele lokal dan Indian catfish (H. fossilis) menggunakan program Genetyx versi 7.0 disajikan dalam Gambar 5. Motif TGACG pada promoter $\beta$-aktin C. batrachus pada nt. 814-818. 
Verifikasi penjajaran elemen transkripsi antara promoter $\beta$-aktin ikan lele lokal dan yellow catfish (Pelteobagrus fulvidraco) juga mengindikasikan keberadaan ketiga elemen transkripsi dalam promoter $\beta$-aktin kedua jenis catfish tersebut (Gambar 6).
Elemen CAAT box sebagai sinyal untuk faktor transkripsi RNA polimerase terletak di depan elemen TATA box, pada posisi nt. 35-42 untuk promoter $\beta$-aktin C. batrachus dan posisi nt. 16-19 untuk P. fulvidraco (Gambar 6). Motif CArG terletak pada nt. 615-623 (pro-
C. batrachus. txt
H. fossilis.txt

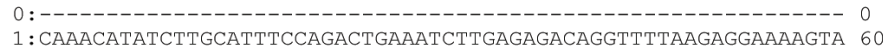
C. batrachus.txt
H. fossilis.txt
$0:---1---10$
c. batrachus.txt
H. fossilis.txt
61: TTCACAGGGAGGAGCAGCCTGTGCTCTGCTGTGTTTGAATGATCAGATAAGCAGGGGGAC 120
C. batrachus. txto
21: TTGCTCGACAGCTTTATACAGGTTCATATTTTATATTTATTTATATTTGAACTTTGTAAA 180
H. fossilis.txt
181: ССTCTATATGTATTAATATTTGTTCAAGAACATATATCTTAGATTAGGCCTCACATCAAT 240
c. batrachus.txt
fossilis.txt
1: $\mathrm{ACCTT} \cdot \mathrm{TCCCCTAGCCCGTTACTGITATCGCCTCC}$
C. batrachus.txt
H. fossilis.txt
C. batrachus.txt
- fossilis.txt
C. batrachus.txt
H. fossilis.txt
C. batrachus.txt
H. fossilis.txt
C. batrachus.txt
. fossilis.txt
c. batrachus.txt
H. fossilis.txt
1:-
301: CCACAGCGTGCACCCGACGTGCCCCAGTGAGTGACGCTGGACCAATCACAGCCGCGATTC 360
14: CGAAAAGGGTCCATTT---TAGACGGCCATGT---GGAGCG--TATAAA-ACCAGGCGCC 64 361: CGAAAGTTTACCTTTTATGGAAAGGGCCGGGCAACGGACGGACTATAAATACCACGCCCA 420
65: CAGACTCCCACTTCACTT-TGAGCTCCTCCACACGCAGCTAGTGCGGAATATCATCTGCC 123 421: CGGCTAGCAAATTCACTACTGAGCGCCGTCACAC-CAGCTTGTGCGGA-TATCATTCGCC 478
124 : C--AACCAAATTTATTTTTTCTTAAGCCGACAACCCCCAAATCTTAAGGTAAGTTTTTTT 181

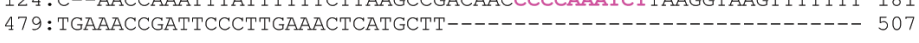
182: CCCCCTTTCCTCCTGGTATTGTTATTACTGTTAGCAATAGTAATTGCAGTAACAATAGTA 241

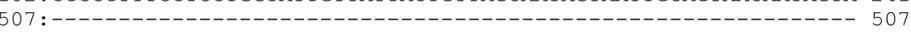
242: ACATTGCTATTTATGTATGCAAGGGTTTAATTGTAAAAACTATATATATATTTTTATAA 301

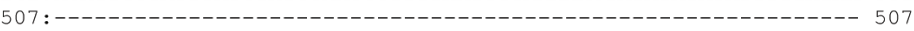
c. batrachus. txt 302: ATTAATGAATGACTGCAAAAAGAACAATACGTTTTCCCTTTATCATGCAGCGATATTAAA 361

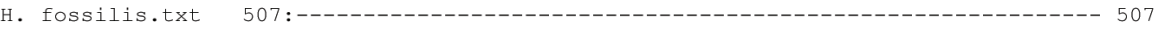
c. batrachus.txt 362: CTAGACAGGAATTATTTTTGTAAATTTTTACCTCAGGTTTTTTTTTTTTTTTCCCTGGGG 421
H. fossilis.txt 507:---
c. batrachus.txt 422:GCTAAAAGCCCCGTAAAACGGCGGGGAGGGGGGGGTTTTTTTTTATTTCTATAAATGAAA 481
H. fossilis.txt 507:---0.--
c. batrachus.txt 482: AAACCGTTTTTTGCCCTGATTATTAAAAAGCGGAGGAAGACCCGTATTTGTCGACGATAA 541
H. fossilis.txt 507:-- 50
C. batrachus. txt 542:TCACAAAAAAAGCGGGGGCGGGGGCCTCCCCCGTTTTTTCCACCTCCCCCCCGGAGAGG 601

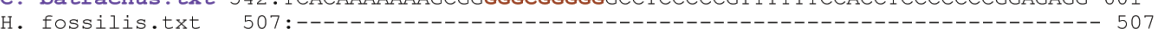
c. batrachus.txt 602:GTAGGATTTCACCCAAATTGGGACAACGAGACCCCTGGGGTAATTCGCTGCCTACCCCTG 661

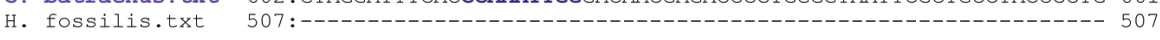
c. batrachus text 662:GGCACTTGAAAAGGGGGGCCCAGTCGTGCTTAAGGCTGTCAAGCCAAGAAGGCTCCCCCA 721

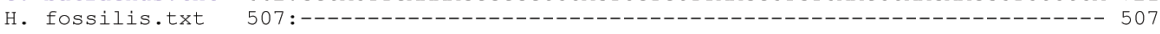
c. batrachus.txt 722:TTTTTTTCTCGCTAGGGGGGGGGCCAGAAAAAATAATATATTTTTTTTATTTTATACCT 781

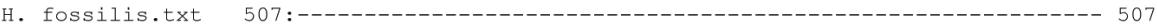
c. batrachus.txt 782:ACTTCCTCACAACTGTACAAAAAAAAGCCACTGACGAGCTCTTGTTATTACAACACCCAG 841

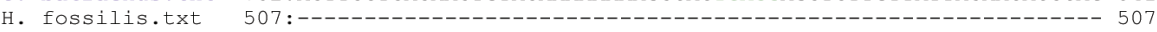
c. batrachus.txt 842:AGATATTGTCCGTCTTATAATTTTTTTTTCTAAAGGCGCCACAAAGCGGACCACACACTT 901
H. fossilis.txt 507:--
c. batrachus.txt 902:AAATCATAGTTAAGTAAGGCCGCCTTGTTGGTGAGCAAGTATACAGGACCGGGAAGTAGA 961
H. fossilis.tit 507:--
c. batrachus.txt 962:GATAGAATGAGTTGATAAAATTAAAATATAAATTTGTTCAGNNTGAACGGAGGCCTGCCC 1021
H. fossilis.txt 507:---
C. batrachus.txt1022: GGGCTCTGCAGAT 1034
H. fossilis.txt 507:------ 507
Keterangan (Notes):
CAAT box $=$ Sekuen conserved (Conserved sequence) GGCCAATCT (CCCCAATCT)
CArG = Sekuen conserved (Conserved sequence) $\mathrm{CC}(\mathrm{A} / \mathrm{T})_{6} \mathrm{GG}$
TATA box $=$ Sekuen conserved (Conserved sequence) TATAAA
GC box = Sekuen conserved (Conserved sequence) GGGCGGG
TGACG = Faktor pertumbuhan dari hipofisa (Factor of pituitary growth)

Gambar 5. Penjajaran elemen transkripsi promoter $\beta$-aktin ikan lele lokal ( $C$. batrachus) dan Indian catfish (H. fossilis)

Figure 5. Transcription element alignment $\beta$-actin promoter walking catfish (C. batrachus) and Indian catfish (H. fossilis) 


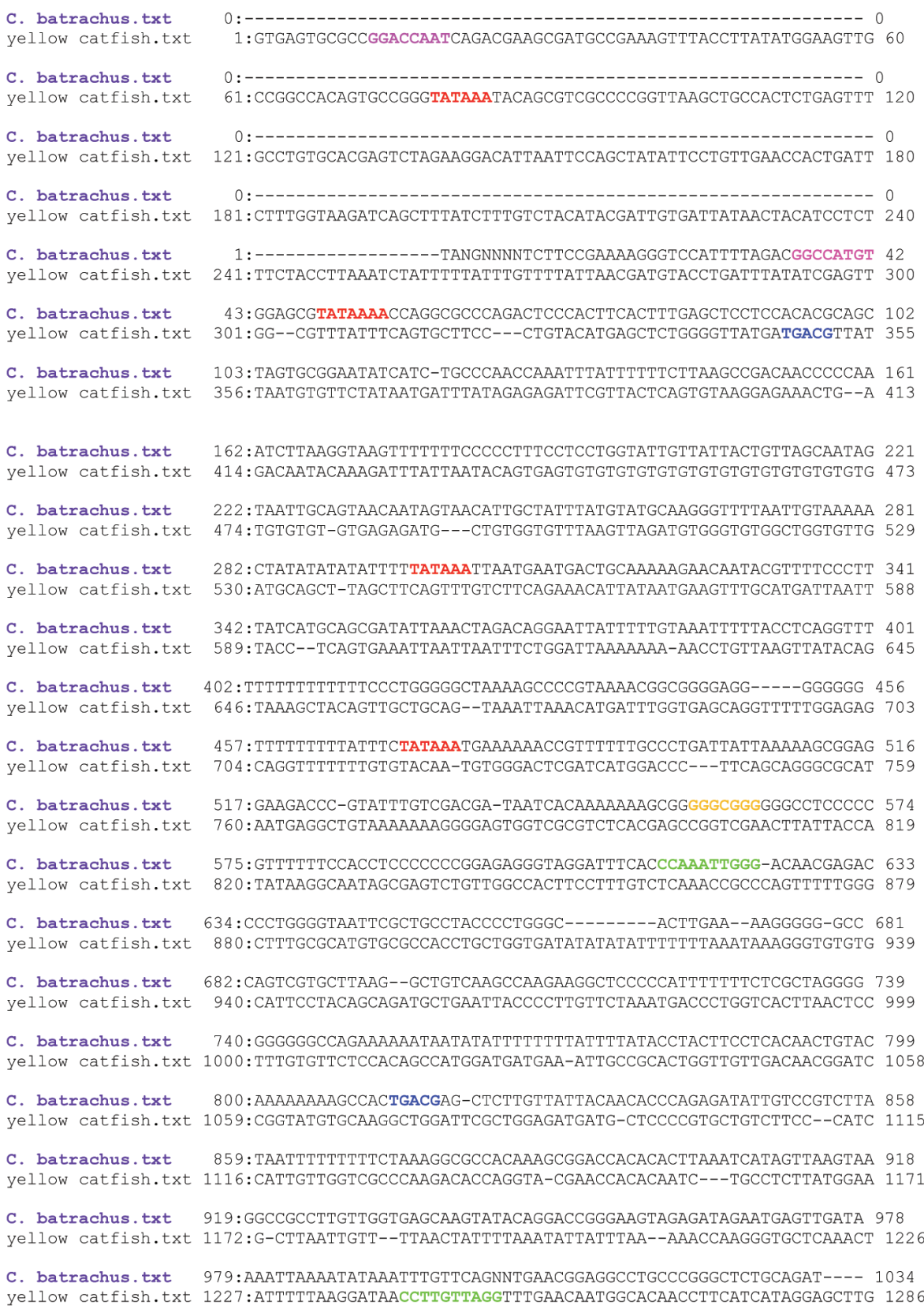

Gambar 6. Penjajaran elemen transkripsi promoter $\beta$-aktin ikan lele lokal $(C$. batrachus) dan yellow catfish (Pelteobagrus fulvidraco)

Figure 6. Transciption element alignment $\beta$-actin promoter walking catfish (C. batrachus) and yellow catfish (Pelteobagrus fulvidraco)

moter $\beta$-aktin C. batrachus) dan terletak pada nt. 12321241 untuk P. fulvidraco. Boks TATA sebagai core promoter untuk ikan lele lokal (C. batrachus) terletak pada nt. 49-54 dan nt. 296-302, serta 472-477, sementara untuk P. fulvidraco pada posisi 78-83. Pada promoter $\beta$-aktin $C$. batrachus, motif TGACG terletak nt. 814-
818, sedangkan pada $P$. fulvidraco pada nt. 348-352. GC box hanya terdapat pada promoter $\beta$-aktin $C$. batrachus pada posisi nt. 558-564. Berdasarkan interprestasi penjajaran elemen-elemen transkripsi (CAAT box, motif $C A r G$, dan TATA box) yang terkandung dalam sekuen promoter $\beta$-aktin ikan lele lokal dengan Indian 
catfish dan yellow catfish (Gambar 5 dan 6), memperkuat keyakinan bahwa sekuen yang teramplifikasi adalah promoter $\beta$-aktin ikan lele lokal (C. batrachus).

Interaksi di antara elemen-elemen transkripsi termasuk motif TGACG yang terkandung dalam sekuen promoter $\beta$-aktin ketiga jenis catfish tersebut sangat dibutuhkan untuk mencapai kadar tinggi transkripsi (Fletcher \& Hew, 2001).

Berdasarkan hasil pengolahan sekuen dengan program TF Bind pada sekuen pCbBA, diperoleh sekuen TATA box yang merupakan core promoter, sekuen CAAT yang mengindikasikan sekuen enhancer, sekuen CCAT box, dan motif CArGG, sehingga terbukti bahwa sekuen yang terkopi oleh primer pBA-Cs-F dan pBA-Cs-R adalah promoter $\beta$-aktin lele lokal.

Verifikasi Sisipan GH Lele Dumbo dalam E. coli JM 109 Pembawa pTarget Rekombinan

Hasil isolasi vektor rekombinan yang mengandung pTarget dengan sisipan gen GH lele dumbo, dideteksi menggunakan primer ORF-GH-F dan ORF-GH-R dan elektroforesis gel agarose $0,8 \%$. Elektroforegram hasil deteksi tersebut disajikan pada Gambar 7.

Hasil cek elektroforesis isolasi vektor rekombinan (pTarget-GH RNA3 lele dumbo) yang disajikan pada Gambar 7, terlihat bahwa fragmen DNA vektor rekombinan yang terdeteksi mengalami konfirmasi dalam bentuk DNA supercoiled (terdapat dua fragmen DNA pada ukuran di atas 3.000 bp dan fragmen DNA pada ukuran di bawah $8.000 \mathrm{bp})$. Bentuk DNA tersebut menandakan fragmen DNA vektor rekombinan (pTargetGH RNA3 lele dumbo) masih melingkar (circular) (Alimuddin et al., 2010), dan secara teoritis hasil ini mengindikasikan bahwa klon-klon bakteri E. coli strain JM 109 dalam stok gliserol tersebut membawa vek- tor pTarget yang mengandung sekuen penyandi GH lele dumbo.

Verifikasi keberadaan gen hormon pertumbuhan lele dumbo (GH RNA3 lele dumbo) dalam vektor pTarget yang terkandung di dalam sel kompeten E. coli JM 109 dapat dikonfirmasi dengan menggunakan primer ORF-Cg-F dan ORF-Cg-R untuk deteksi gen GH lele dumbo. Hasil konfirmasi pTarget yang membawa gen GH tersebut ditunjukkan pada Gambar 8.

Keberadaan fragmen penyandi GH lele dumbo (sampel $\mathrm{GH}_{2}(1), \mathrm{GH}_{2}(2)$, dan uncut vektor pTarget) terdeteksi pada Gambar 8 dengan ukuran fragmen sebesar 600 bp, yang menunjukkan bahwa sisipan gen hormon pertumbuhan lele dumbo terdapat dalam vektor pTarget, serta terkandung di dalam sel kompeten $E$. coli JM 109 (stok gliserol). Konstruksi vektor ekspresi untuk pembuatan ikan transgenik ini terdapat dalam klon-klon bakteri dengan kode sampel pTarget- $\mathrm{GH}_{2}$ (1), pTarget- $\mathrm{GH}_{2}$ (2) dan pada vektor rekombinan (pTarget-CMV-GH RNA ${ }_{2}$ ) yang tidak dipotong dengan restriksi EcoRI (uncut vektor). Hasil ini membuktikan bahwa konstruksi vektor ekspresi dengan promoter CMV yaitu pTarget-CMV-GH ${ }_{2}$ (1) dan pTarget-CMV-GH (2) untuk pembuatan ikan transgenik telah berhasil dibuat.

Klon-klon dari sampel lain (aliquot) yang diverifikasi keberadaan sisipan gen GH lele dumbo dengan primer ORF-Cg-F dan ORF-Cg-R juga menunjukkan hasil yang sama dengan sampel hasil isolasi vektor rekombinan pTarget-CMV-GH RNA 2 (1) dan pTarget-CMV-GH $\mathrm{RNA}_{2}(2)$ sebelumnya. Klon koloni sampel hasil isolasi pTarget-CMV-GH RNA $\left(\mathrm{B}_{2}\right)$; p Target-CMV-GH RNA ${ }_{3}\left(\mathrm{~B}_{3}\right)$; pTarget-CMV-GH RNA 2 (1) dan pTarget-CMV-GH RNA (2) yang membawa sisipan gen hormon pertumbuhan lele dumbo disajikan pada Gambar 9.

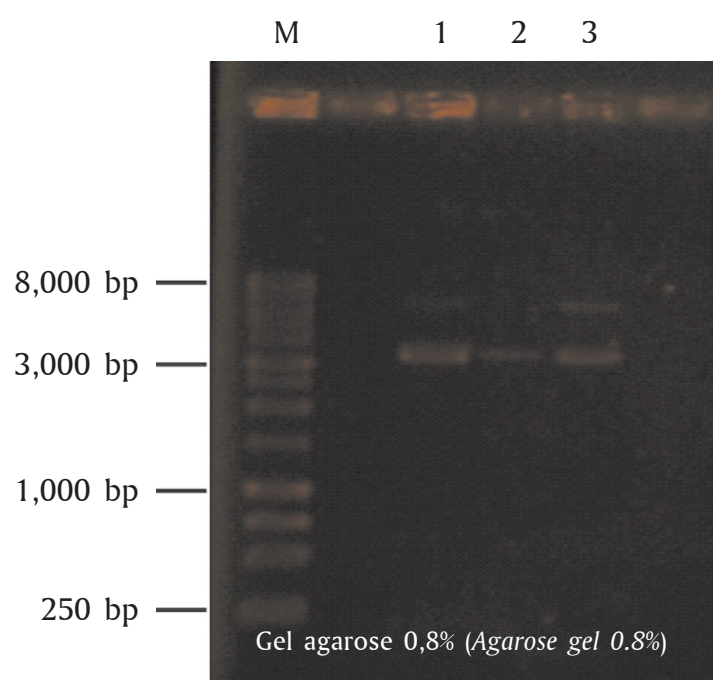

Keterangan (Notes):

$\mathrm{M}=$ Marker DNA ladder $1 \mathrm{~kb}$ (Marker $1 \mathrm{~kb}$ DNA Ladder)

$1=$ Hasil isolasi vektor pTarget-GH RNA3-(B)-1 (Isolation results of pTarget-GH RNA3-(B)-1 vector)

$2=$ Hasil isolasi vektor pTarget-GH RNA3-(B)-2 (Isolation results of pTarget-GH RNA3-(B)-2 vector)

$3=$ Hasil isolasi vektor pTarget-GH RNA3-(B)-3 (Isolation results of pTarget-GH RNA3-(B)-3 vector)

Gambar 7. Elektroforegram hasil isolasi pTarget-GH RNA3 lele dumbo

Figure 7. Electrophoregram results isolation pTarget-GH RNA3 African catfish 


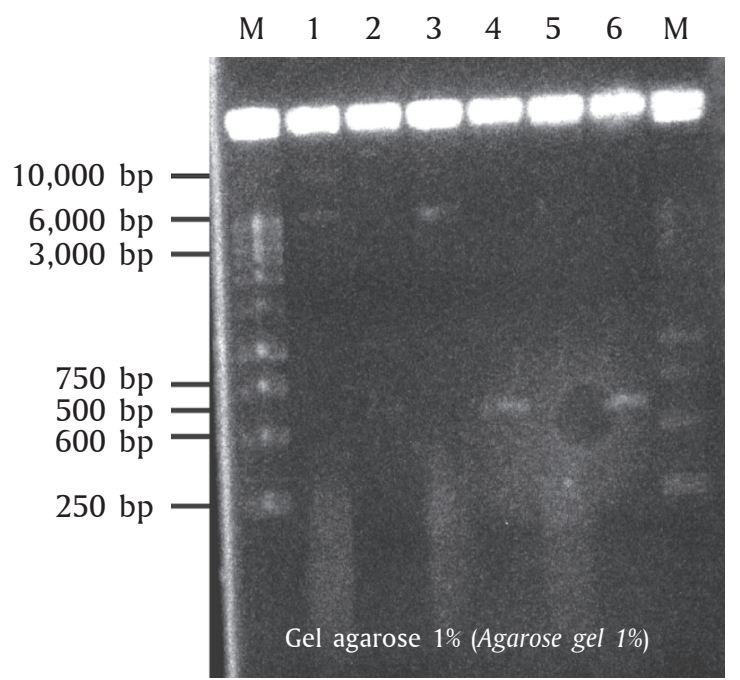

Keterangan (Notes):

$\mathrm{M}=$ Marker DNA ladder $1 \mathrm{~kb}$ (Marker $1 \mathrm{~kb}$ DNA Ladder)

1 = Sampel hasil isolasi vektor pTarget-GH3 (uncut vektor) (Sample isolation results pTarget-GH3 vector (uncut vector))

2 = PCR dari sampel hasil isolasi vektor pTarget-GH3 (uncut vektor) $P C R$ from samples isolation results pTarget-GH3 vector (uncut vector)

$3=$ Hasil isolasi vektor pTarget-GH ${ }_{2}$ (1) (Isolation results pTarget-GH2 (1) vector)

$4=$ PCR hasil isolasi vektor pTarget- $\mathrm{GH}_{2}(1)(P C R$ isolation results pTarget-GH2 (1) vector)

$5=$ Sampel hasil isolasi vektor pTarget- $\mathrm{GH}_{2}(2)$ (Samples isolation results pTarget-GH2 (2) vector)

6 = PCR sampel hasil isolasi vektor pTarget-GH $\mathrm{GH}_{2}(2)$ (PCR samples isolation results pTarget-GH2 (2) vector)

Gambar 8. Konfirmasi pTarget pembawa GH lele dumbo

Figure 8. Confirmation pTarget carrier African catfish GH

Hasil elektroforegram pada Gambar 9, khususnya sampel hasil isolasi pTarget-GH RNA $3\left(\mathrm{~B}_{2}\right)$, pTarget-GH $\mathrm{RNA}_{3}\left(\mathrm{~B}_{3}\right)$ dan pTarget-GH RNA $\left(\mathrm{A}_{1}\right)$ terdapat DNA vektor ekspresi (pTarget) pada ukuran sekitar $6.000 \mathrm{bp}$, sesuai dengan ukuran vektor pTarget (5.670 bp) pada semua sampel tersebut (sumur ke-1, 3, dan 5) (Gambar 9) dalam bentuk DNA linier yang terkandung dalam sel kompeten E. coli JM 109 stok gliserol. Konfirmasi ini memberikan keyakinan bahwa vektor ekspresi yang dikloning dan ditransformasikan ke sel kompeten dan disimpan cukup lama dalam gliserol tersebut, memiliki kualitas DNA vektor sangat baik (dalam keadaan utuh), dan konfirmasi sisipan gen hormon pertumbuhan lele dumbo pada masing-masing sampel tersebut terdeteksi dengan ukuran fragmen 600 bp menggunakan primer ORF-Cg-F dan ORF-Cg-R (sumur ke-2, 4, dan 6) (Gambar 9).

Sementara, pada sampel hasil kultur cair yaitu: pTarget-GH RNA 2 (1), pTarget-GH RNA 2 (2), dan uncut pTarget-GH RNA ${ }_{3}$, fragmen DNA vektor sampel tersebut berbentuk supercoiled yang mengindikasikan DNA dalam keadaan konfirmasi dengan bentuk melingkar. Bentuk seperti ini umum dijumpai pada fragmen DNA vektor yang baru dikloning ke dalam sel kompeten dan dalam jangka tertentu akan kembali dalam bentuk normal (bentuk sirkular). Indikasi bentuk supercoiled ini ditunjukkan dengan munculnya pita-pita ganda di atas 6.000 bp (ukuran vektor pTarget sebesar 5.670 bp) (sumur ke-7, 8, 9, 10, 11, dan ke-12) (Gambar 9). Verifikasi sisipan GH lele dumbo dalam vektor pTarget hasil kultur cair juga diperoleh tepat dengan ukuran fragmen sebesar 600 bp (sumur ke-7, 8, 9, 10, 11, dan ke-12) (Gambar 9). Dengan demikian dalam perakitan konstruksi vektor ekspresi gen hormon pertumbuhan lele dumbo diperoleh stok konstruksi vektor sebanyak enam sampel: (pTarget-CMV-GH RNA
$\left(\mathrm{B}_{2}\right)$, pTarget-CMV-GH $\mathrm{RNA}_{3}\left(\mathrm{~B}_{3}\right)$, pTarget-CMV-GH $\mathrm{RNA}_{3}$ (1), pTarget-CMV-GH RNA $(1)$, pTarget-CMV-GH $\mathrm{RNA}_{2}$ (2), dan uncut pTarget-CMV-GH RNA ${ }_{3}$.

\section{Digesti pTarget Rekombinan dengan Enzim Restriksi I-Ppo I}

Untuk mengganti promoter CMV pada vektor ekspresi pTarget-CMV-GH lele dumbo, maka diperlukan pengerjaan pemotongan (digesti) tapak Sgf-I dan IPpo I pada vektor pTarget-CMV-GH lele dumbo, sehingga sebagian fragmen promoter CMV dikeluarkan dan promoter tersebut tidak berfungsi kemudian disisipkan dengan fragmen promoter $\beta$-aktin lele lokal yang telah diperoleh. Penggantian promoter virus (CMV) dengan $\beta$-aktin lele lokal ini dimaksudkan untuk membuat konstruksi vektor ekspresi all catfish pada tata konstruksi ikan transgenik, sehingga mudah diterima oleh konsumen ikan sebagai bahan pangan dan elemen cis-acting promoter $\beta$-aktin lele lokal mudah dikenali oleh faktor trans-acting dari ikan sekerabat dibandingkan yang berasal dari virus (Alam et al., 1996; Alimuddin, 2003; Ge et al., 2012).

Hasil produk digesti pTarget-CMV-GH lele dumbo dengan enzim restriksi I-Ppo I disajikan pada Gambar 10. Berdasar hasil elektroforegram Gambar 10, khususnya untuk sampel pTarget-ORF-GH ${ }_{2}(2)$ dan pTarget$\mathrm{ORF} \mathrm{GH}_{3}\left(\mathrm{~B}_{2}\right)$ (sumur ke-1 dan ke-2) (Gambar 10), diperoleh fragmen DNA berukuran sekitar 6.000 bp, yang mengindikasikan ukuran vektor rekombinan (pTargetCMV-GH lele dumbo) sebesar $6.270 \mathrm{bp}$, sehingga produk digesti dengan enzim I-Ppo I pada kedua sampel tersebut terverifikasi dengan benar.

Khusus untuk verifikasi hasil pemotongan fragmen pTarget-CMV-GH lele dumbo dengan Sgf-I dan I-Ppo I, maka hasil fragmen yang dipotong dapat dilihat pada 


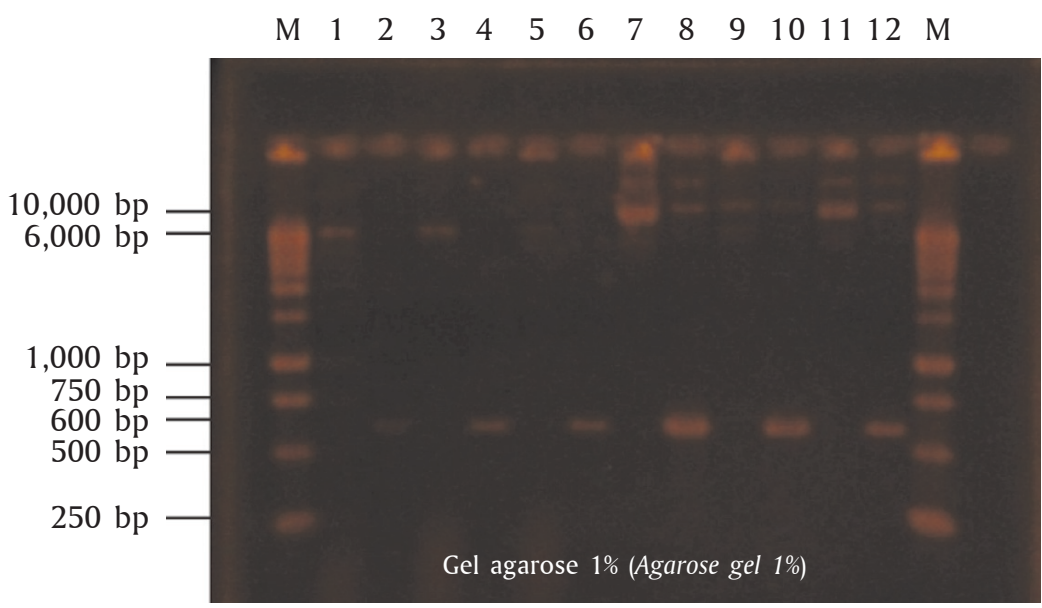

Keterangan (Note):

$\mathrm{M}=$ Marker DNA ladder $1 \mathrm{~kb}$ (Marker $1 \mathrm{~kb}$ DNA Ladder)

$1=$ Hasil isolasi pTarget- $\mathrm{GH}_{3}-\left(\mathrm{B}_{2}\right)$ stok gliserol (Isolation results pTarget-GH3-(B2) of gliserol stock)

2 = Konfirmasi PCR hasil isolation pTarget-GH RNA $-\left(\mathrm{B}_{2}\right)$ stok gliserol pakai primer ORF-Cg-F dan ORF-Cg-R $P C R$ confirmation of isolation results pTarget-GH RNA3-(B2) of glierol stock use ORF-Cg-F and ORF-Cg-R primers

$3=$ Hasil isolasi pTarget- $\mathrm{GH}_{3}-\left(\mathrm{B}_{3}\right)$ stok gliserol (Isolation results pTarget-GH3-(B3) of gliserol stock)

$4=$ Konfirmasi PCR hasil isolasi pTarget-GH RNA $-\left(\mathrm{B}_{3}\right)$ stok gliserol pakai primer ORF-Cg-F dan ORF-Cg-R $P C R$ confirmation of isolation results pTarget-GHRNA3-(B3) of gliserol stock use ORF-Cg-F and ORF-Cg-R primers

$5=$ Hasil isolasi pTarget- $\mathrm{GH}_{3}-\left(\mathrm{A}_{1}\right)$ stok gliserol (Isolation results pTarget-GH3-(A1) of gliserol stock)

$6=$ Konfirmasi PCR hasil isolasi pTarget-GH RNA $-\left(\mathrm{A}_{1}\right)$ stok gliserol pakai primer ORF-Cg-F dan ORF-Cg-R $P C R$ confirmation of isolation results pTarget-GH RNA3-(A1) of gliserol stock use ORF-Cg-F and ORF-Cg-R primers

7 = Uncut pTarget-GH RNA ${ }_{3}$ hasil isolasi vektor rekombinan (Isolation results uncut recombinant vector pTargetGH RNA3)

$8=$ Konfirmasi PCR pTarget-GH RNA 3 hasil isolasi vektor rekombinan (primer ORF-Cg-F dan ORF-Cg-R) $P C R$ confirmation isolation results of recombinant vector pTarget-GH RNA3 (ORF-Cg-F and ORF-Cg-R primers)

$9=$ Hasil isolasi pTarget-GH RNA 2 (1) (Isolation results of pTarget-GH RNA2 (1))

$10=$ Konfirmasi PCR hasil isolasi pTarget-GH RNA $(1)$ dengan primer ORF-Cg-F dan ORF-Cg-R $P C R$ confirmation isolation results of pTarget-GH RNA2 (1) with ORF-Cg-F and ORF-Cg-R primers

$11=$ Hasil isolasi pTarget-GH RNA 2 (2) (Isolation results of pTarget-GH RNA2 (2))

$12=$ Konfirmasi PCR hasil isolasi pTarget-GH RNA 2 (2) dengan primer ORF-Cg-F dan ORF-Cg-R $P C R$ confirmation isolation results of pTarget-GH RNA2 (2) with ORF-Cg-F and ORF-Cg-R primers

Gambar 9. Konfirmasi sisipan GH lele dumbo pada klon E. coli JM 109

Figure 9. Confirmation of African catfish GH inserts in clones of E. coli JM 109

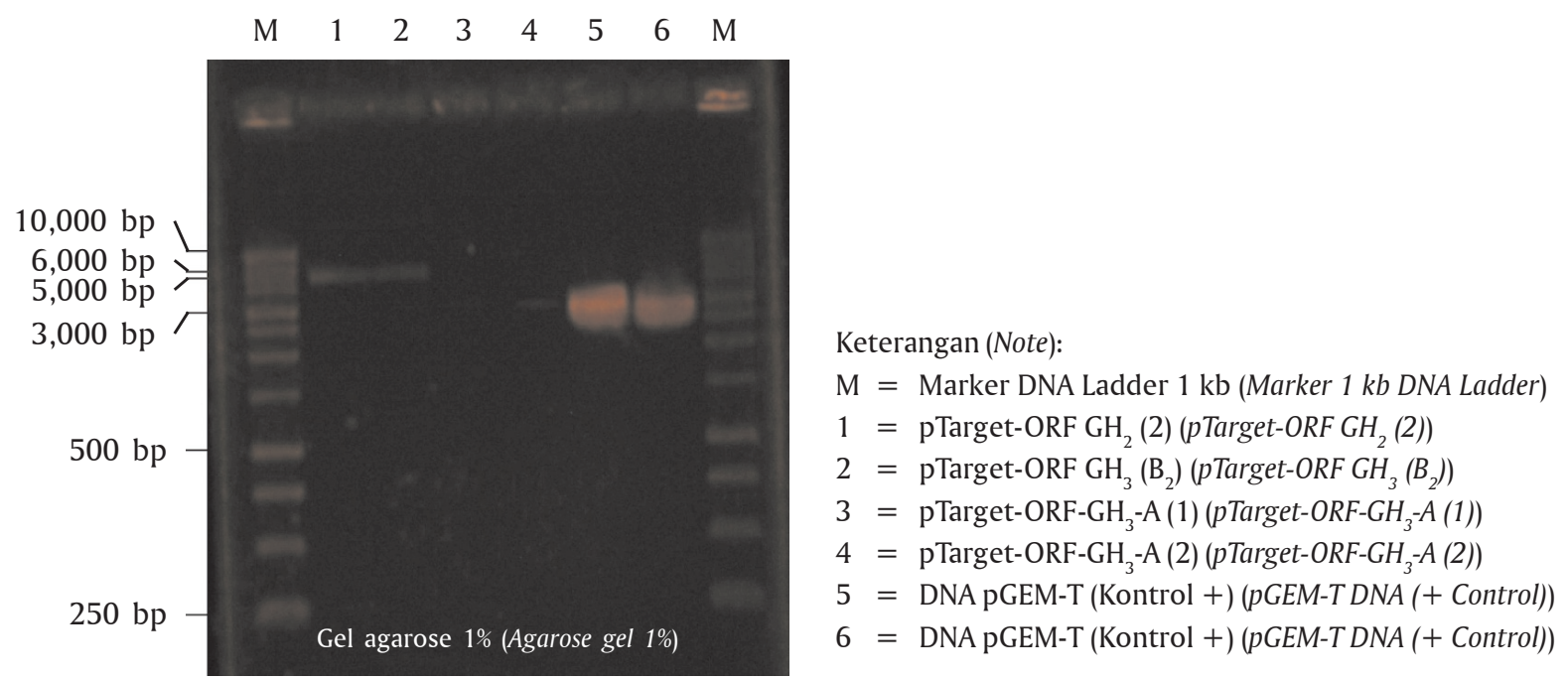

Gambar 10. Produk digesti pTarget-CMV-GH lele dumbo dengan I-Ppo I

Figure 10. Digestion product of pTarget-CMV-GH African catfish with I-Ppo I 


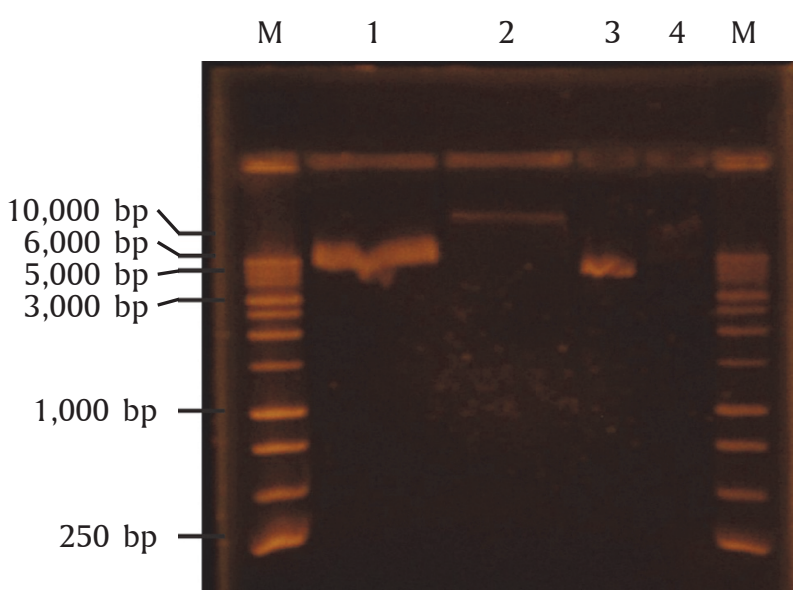

Gambar 11. Elektroforegram produk digesti vektor rekombinan dengan $S g f-\mathrm{I}$

Figure 11. Electrophoregram digestion products of the recombinant vector with $\mathrm{Sg} f-\mathrm{I}$

Gambar 11. Vektor rekombinan yang hanya dipotong dengan Sgf-I pada suhu inkubasi $37^{\circ} \mathrm{C}$ semalaman (overnight) berada pada ukuran sekitar 6.000 bp (sumur ke-1) (Gambar 11), sedangkan pada sumur ke-2 (Gambar 11), ukuran vektor rekombinan yang dipotong SgfI di atas 6.000 bp, yang mengindikasikan fragmen belum terpotong secara sempurna. Sebaliknya fragmen vektor rekombinan yang dipotong $S g f-I$ pada suhu inkubasi $37^{\circ} \mathrm{C}$ selama tiga jam (sumur ke-3) (Gambar 11), menunjukkan hasil potongan berkisar $6.000 \mathrm{bp}$, yang menunjukkan hasil digesti yang benar, seperti halnya pada ukuran fragmen yang ditunjukkan pada sumur ke-1 (Gambar 11). Sementara untuk vektor rekombinan pTarget-CMV-GH lele dumbo (ukuran $6.270 \mathrm{bp}$ ) yang dipotong oleh enzim I-Ppo I dan kemudian dipotong $S g f$-I (sumur ke-4) (Gambar 11) dengan fragmen yang terpotong sekitar 187 bp menunjukkan ha- sil yang benar (walaupun bentuk fragmen DNA masih supercoiled), dengan ukuran sekitar $6.083 \mathrm{bp}$ (di atas $6.000 \mathrm{bp}$ ). Dengan demikian telah diperoleh situs restriksi Sgf-I dan I-Ppo I pada tapak vektor rekombinan pTarget-GH lele dumbo untuk mengganti (replacement) promoter CMV dengan promoter $\beta$-aktin lele lokal pada vektor tersebut.

Pada sumur ke-1 (Gambar 11), hasil digesti vektor pTarget-GH3B2 menghasilkan fragmen linier berukuran sekitar 6.000 bp setelah dipotong dengan enzim Sgf-I, dan selanjutnya gel dari fragmen linier tersebut dipurifikasi menggunakan Wizard PCR clean up kit (Promega) untuk dipotong kembali menggunakan enzim restriksi lain, yaitu I-Ppo I, dalam upaya mengganti promoter CMV dengan promoter $\beta$-aktin lele lokal pada vektor pTarget. Formula campuran reaksi digesti dengan enzim I-Ppo I untuk fragmen pTarget-GH3B2 (Sgf-I) yaitu: Sterile Deionized Water (SDW) sebanyak 11,5 $\mu \mathrm{L}$; buffer RE (Restriction Enzyme) 10x sebanyak $2 \mu \mathrm{L}$; BSA (Bovine Serum Albumin) sebanyak 0,5 $\mu \mathrm{L}$; DNA vektor (pTarget-GH3B2-Sgf-I) sebanyak $5 \mu \mathrm{L}$ dan enzim $I$ Ppo I sebanyak $1 \mu \mathrm{L}$. Elektroforesis gel agarose $1 \%$ hasil digesti vektor ekspresi rekombinan dengan I-Ppo I tersebut disajikan dalam Gambar 12.

Berdasarkan ukuran DNA vektor pTarget-GH3B2 sekitar 6.270 bp yang dipotong dengan enzim Sgf-I dan I-Ppo I (sekuen vektor dibuang sekitar 187 bp), hasil akhir produk digesti kedua enzim restriksi yang diperoleh sebesar 6.083 bp. Ukuran fragmen linier produk digesti kedua enzim ini terdeteksi pada Gambar 12 (sumur ke-1, 2, dan 3) pada posisi $6.000 \mathrm{bp}$. Dengan demikian, diperoleh tiga sampel DNA vektor rekombinan, yang telah dipotong sisi restriksinya dengan enzim Sgf-I dan I-Ppo I untuk insersi sekuen promoter $\beta$-aktin lele lokal.

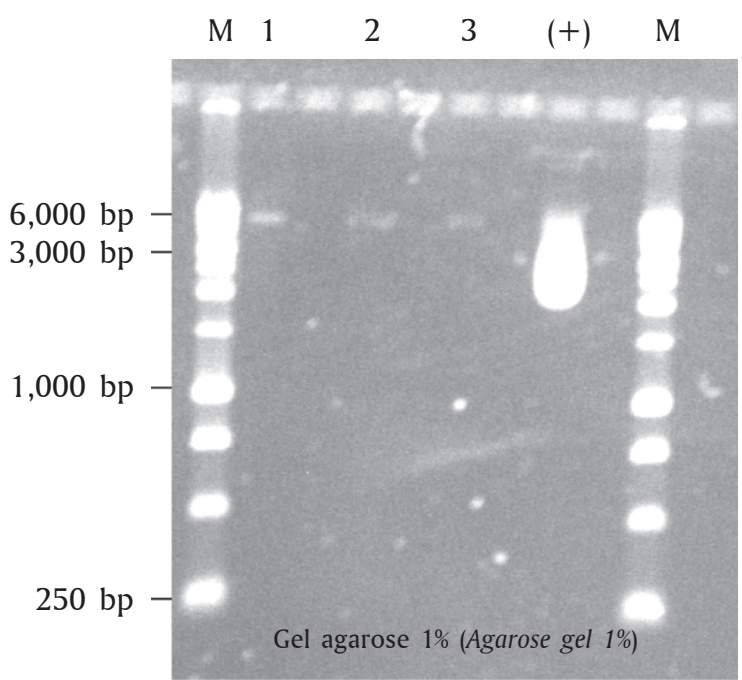

Keterangan (Note):

$\mathrm{M}=$ Marker DNA Ladder $1 \mathrm{~kb}$ (Marker $1 \mathrm{~kb}$ DNA Ladder)

1 = pTarget-CMV-GH3B2 dipotong Sgf-I, lalu dipotong I-Ppo I pTarget-CMV-GH3B2 cutting with Sgf-I and cutting with I-Ppo I

2 = pTarget-CMV-GH3B2 dipotong Sgf-I, lalu dipotong I-Ppo I pTarget-CMV-GH3B2 cutting with Sgf-I and cutting with I-Ppo I

3 = pTarget-CMV-GH3B2 dipotong Sgf-I, lalu dipotong I-Ppo I pTarget-CMV-GH3B2 cutting with Sgf-I and cutting with I-Ppo I

$(+)=\operatorname{Kontrol}(+)$ pGEM-T yang disediakan dari kit I-Ppo I pGEM-T (+) control provided from I-Ppo I kit

Gambar 12. Produk digesti vektor rekombinan (pTarget-GH3B2) dengan Sgf-I dan I-Ppo I

Figure 12. Digestion product of recombinant vector (pTarget-GH3B2) with Sgf-I and I-Ppo I 


\section{Ligasi Vektor Rekombinan (pTarget-GH3B2-Sgf- I-I-Ppo I) dan Promoter $\beta$-Aktin Lele Lokal}

Produk digesti vektor rekombinan dengan enzim Sgf-I dan I-Ppo I selanjutnya diligasikan dengan sekuen promoter $\beta$-aktin lele lokal $(\mathrm{pC} b \mathrm{BA})$ untuk menghasilkan konstruksi pTarget-pCbBA-GH3B2 sebagai vektor ekspresi gen hormon pertumbuhan untuk produksi ikan lele lokal transgenik. Rasio vektor rekombinan : promoter $\beta$-aktin lele lokal yang digunakan dalam campuran reaksi ligasi tersebut sebesar 1:3. Formula reaksi ligasi sebagai berikut: T4 DNA ligase 10x buffer sebanyak $1 \mu \mathrm{L}$; p Target-GH3B2 (Sgf-I-I-Ppo I) sebanyak $1 \mu \mathrm{L}$; promoter $\beta$-aktin lele lokal (pCbBA) sebanyak $3 \mu \mathrm{L}$; enzim T4 DNA ligase sebanyak $1 \mu \mathrm{L}$; dan SDW sebanyak $4 \mu \mathrm{L}$. Selain itu, juga digunakan rasio vektor rekombinan : promoter $\beta$-aktin lele lokal sebesar $1: 2$ dalam reaksi campuran ligasi tersebut.

Tahapan selanjutnya adalah pengerjaan transformasi hasil ligasi di atas ke dalam sel kompeten E. coli JM 109, dengan urutan sebagai berikut: mencampurkan $50 \mu \mathrm{L}$ sel kompeten dengan $10 \mu \mathrm{L}$ setiap sampel, kemudian diinkubasikan ke dalam es curai selama 30 menit. Segera dilakukan heat shock setiap sampel pada $42^{\circ} \mathrm{C}$ dalam waterbath selama 90 detik, kemudian diinkubasi kembali dalam es curai selama lima menit. Ditambahkan larutan SOC Broth sebanyak $600 \mu \mathrm{L}$ ke dalam setiap sampel, lalu diinkubasikan pada suhu $37^{\circ} \mathrm{C}$ selama 2-3 jam dengan kecepatan $150 \mathrm{rpm}$ menggunakan shaker incubator. Selanjutnya sampel disentrifugasi $14.000 \mathrm{rpm}$ selama satu menit, kemudian diambil produk transforman $100 \mu \mathrm{L}$ untuk diresuspensi (menggunakan mikropipet) sehingga menjadi larutan suspensi, kemudian di-plating ke cawan petri berisi medium Luria Broth (LB)-agar yang sudah disuplementasi dengan IPTG-X gal-Ampicillin. Cawan petri tersebut dibiarkan selama 15 menit pada suhu ruang, dan selanjutnya diinkubasi ke dalam inkubator dengan suhu $37^{\circ} \mathrm{C}$ selama satu malam (overnight). Hasil transformasi tersebut disajikan dalam Gambar 13, koloni putih transforman yang mengandung sekuen konstruksi pTarget-pCbBA-GH3B2.

Keberadaan fragmen vektor ekspresi rekombinan (pTarget-pCbBA-GH3B2 berukuran 8.383 bp) terdeteksi dari hasil elektroforesis gel agarose $1 \%$ dengan ukuran sekitar 8.000 bp yang terbentuk dari gabungan pTarget-GH3B2 (Sgf-I-I-Ppo I) berukuran 6.083 bp, promoter $\beta$-aktin lele lokal berukuran $1.700 \mathrm{bp}$, dan GH3B2 sebesar 600 bp (Gambar 14).

Bentuk fragmen DNA gabungan pTarget-pCbBA-GH lele dumbo (7.783 bp) (Gambar 14); supercoiled yang ditampakkan dengan dengan pita ganda DNA dan terindikasi fragmen berukuran 8.000 bp sebagai representasi konstruksi vektor pTarget-promoter $\beta$ aktin lele lokal-GH lele dumbo yang mengindikasikan

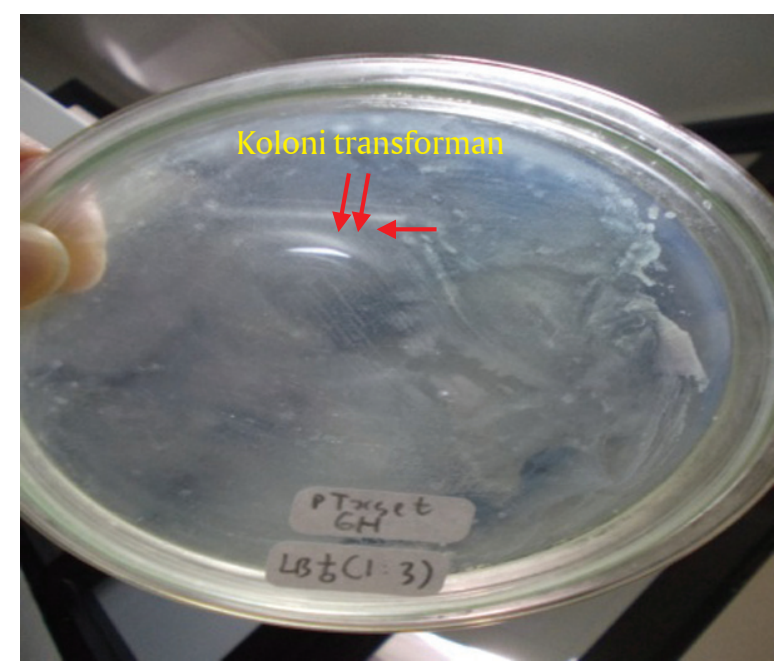

Gambar 13. Koloni transforman pembawa pTarget yang mengandung promoter $\beta$-aktin lele lokal ( $\mathrm{pCbBA}$ ) dan gen hormon pertumbuhan lele dumbo (GH3B2)

Figure 13. pTarget carrier transformant colonies containing $\beta$-actin promoter walking catfish $(p C b B A)$ and African catfish growth hormone gene (GH3B2)

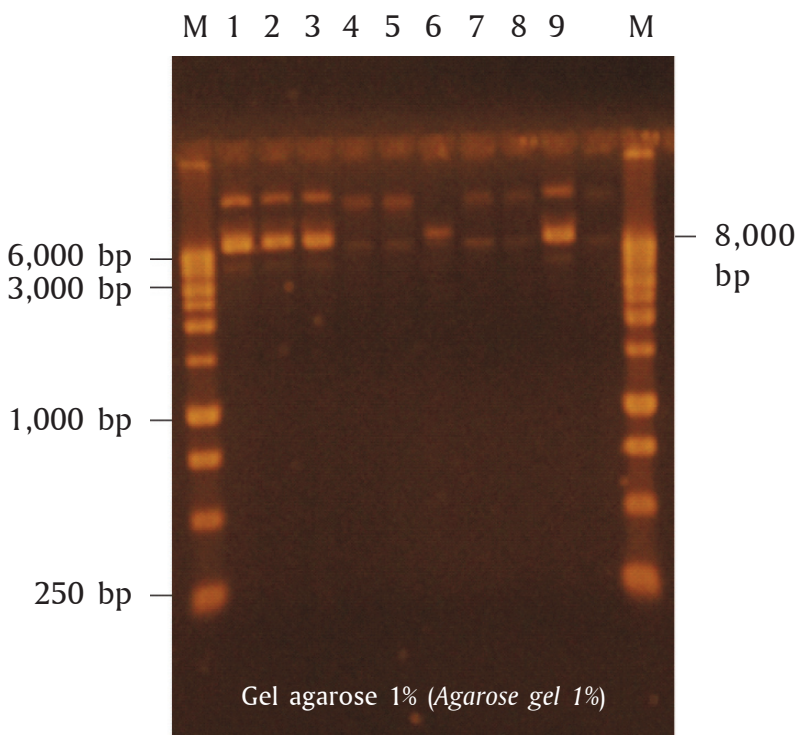

Keterangan (Note):

$\mathrm{M}=$ Marker DNA ladder $1 \mathrm{~kb}$ (Marker $1 \mathrm{~kb}$ DNA Ladder)

$1=$ Konstruksi pTarget-promoter $\beta$-aktin lele lokal betina (rasio 1:3)-GH lele dumbo (aliquot 1) (pTarget- $\beta$-actin promoter female walking fish (ratio 1:3)- African fish GH (aliquot 1) construction)

$2=$ Konstruksi pTarget-promoter $\beta$-aktin lele lokal betina (rasio $1: 3$ )-GH lele dumbo (aliquot 2) (pTarget- $\beta$-actin promoter female walking fish (ratio 1:3)-African fish GH (aliquot 2) construction)

Gambar 14. Konstruksi pTarget-pCbBA-GH lele dumbo (7.783 bp)

Figure 14. pTarget-pCbBA-African catfish GH (7,783 bp) construction 
Lanjutan keterangan Gambar 14 (Figure 14 note continued):

3 = Konstruksi pTarget-promoter $\beta$-aktin lele lokal betina (rasio $1: 2$ )-GH lele dumbo (aliquot 1 ) (pTarget- $\beta$-actin promoter female walking fish (ratio 1:2)-African fish GH (aliquot 1) construction)

$4=$ Konstruksi pTarget-promoter $\beta$-aktin lele lokal betina (rasio 1:2)-GH lele dumbo (aliquot 2 ) (pTarget- $\beta$-actin promoter female walking fish (ratio 1:2)-African fish GH (aliquot 2) construction)

$5=$ Konstruksi pTarget-promoter $\beta$-aktin lele lokal (genom hipofisa-primer pBACS-F dan pBACS-R) (rasio 1:3)-GH lele dumbo (aliquot 1) (pTarget- $\beta$-actin promoter walking fish (genomic pituitary-pBACS-F and pBACS-R primers) (ratio $1: 3$ )African fish $G H$ (aliquot 1) construction)

6 = Konstruksi pTarget-promoter $\beta$-aktin lele lokal (genom hipofisa-primer pBACS-F dan pBACS-R) (rasio 1:3)-GH lele dumbo (aliquot 2) (pTarget- $\beta$-actin promoter walking fish (genomic pituitary-pBACS-F and pBACS-R primers) (ratio 1:3)African fish GH (aliquot 2) construction)

7 = Konstruksi pTarget-promoter $\beta$-aktin lele lokal (genom hipofisa-primer pBACS-F dan pBACS-R) (rasio 1:2)-GH lele dumbo (aliquot 1) (pTarget- $\beta$-actin promoter walking fish (genomic pituitary-pBACS-F and pBACS-R primers) (ratio 1:2)African fish $\mathrm{GH}$ (aliquot 1) construction)

8 = Konstruksi pTarget-promoter $\beta$-aktin lele lokal (genom hipofisa-primer pBACS-F dan pBACS-R) (rasio $1: 2$ )-GH lele dumbo (aliquot 2) (pTarget- $\beta$-actin promoter walking fish (genomic pituitary-pBACS-F and pBACS-R primers) (ratio 1:2)African fish GH (aliquot 2) construction)

$9=$ Konstruksi pTarget-kontrol insert DNA kit (pTarget-insert DNA kit control construction)

keberhasilan ligasi promoter $\beta$-aktin lele lokal ke dalam konstruksi pTarget-GH3B2.

\section{KESIMPULAN DAN SARAN}

\section{Kesimpulan}

Berdasarkan hasil penelitian, dapat disimpulkan bahwa sekuen promoter $\beta$-aktin ikan lele lokal $(C$. batrachus) dapat diisolasi dengan ukuran amplikon sekitar 1.700 bp dengan elemen transkripsi CAAT box, TATA box, GC box, motif CArG, dan TGACG. Sisipan (insert) gen hormon pertumbuhan lele dumbo dari hasil ligasi pTarget-CMV-GH lele dumbo dan sel kompeten yang mengandung vektor rekombinan dapat dideteksi dengan primer ORF-Cg-GH-F dan ORF-CgGH-R. Konstruksi pTarget-promoter $\beta$-aktin lele lokalGH lele dumbo berhasil dibuat.

\section{Saran}

Diperlukan deteksi keberadaan sisipan promoter $\beta$-aktin lele lokal-GH lele dumbo dalam vektor rekombinan pTarget yang terkandung dalam sel kompeten sebelum digunakan lebih lanjut pada pengerjaan elektroporasi vektor tersebut ke dalam sel sperma lele lokal.

\section{DAFTAR ACUAN}

Alam, M.S., Lavender, F.L., lyengar, A., Rahman, M.A., Ayad, H.H., Lathe, R., Morley, S.D., \& Maclean, N. (1996). Comparison of the activity of carp and rat $\beta$-actin gene regulatory sequences in tilapia and rainbow trout embryos. Mol. Reprod. Dev., 45, 47122.

Alimuddin. (2003). Introduction and expression of foreign $\Delta 6$-desaturase-like gene in a teleostean fish. Thesis. Tokyo University of Fisheries, Japan.

Alimuddin, Nugrahani, W., Aliah, R.S., Sumantadinata, K., Faizal, I., Carman, O., \& Yoshizaki, G. (2007). Isolasi dan karakterisasi promoter $\beta$-aktin dari ikan kerapu bebek (Cromileptes altivelis). Jurnal Riset Akuakultur, 2(2), 199-209.

Aranburu, A., Liberg, D., Honore, B., \& Leandersen, T. (2006). CArG box-binding factor-A interacts with multiple motifs in immunoglobulin promoter and has a regulated sub cellular distribution. Eur. J. Immunol., 36, 2192-2202.

Argenton, F., Bernardini, S., Puttini, S., \& Bortolessi, M. (1991). A TGACG motif mediates growth-hormone factor-1/pituitary-transcriptional-activator1-dependent cAMP regulation of the rainbow trout growth hormone promoter. Eur. J. Biochem., 238, 591-598.

Chen, T.T., \& Powers, D.A. (1990). Transgenic fish. Trends Biotechnol., 8, 209-215.

Collares, T., Campos, V.F., Seixas, F.K., Cavalcanti, P.V., Dellagostin, O.A., Moreira, H.L.M., \& Deschamps, J.C. (2010). Transgene transmission in South American catfish (Rhamdia quelen) larvae by spermmediated gene transfer. J. Biosci., 35(1), 1-9.

Dewi, R.R.S.P.S., Alimuddin, Sudradjat, A.O., \& Sumantadinata, K. (2010a). Optimal electroporation condition for sperm mediated gene transfer in stripped catfish (Pangasionodon hypophthalmus). Indonesian Aquaculture Journal, 5(1), 1-10.

Ge, J., Dong, Z., Li, J., Xu, Z., Song, W., Bao, J., Liang, D., \& Li, J. (2012). Isolation of yellow catfish $\beta$ actin promoter and generation of transgenic yellow catfish expressing enhanced yellow flourescent protein. Transgenic Research, 21(5), 99-1004.

Li, L., Chang, M.X., \& Nie, P. (2007). Molecular cloning, promoter analysis and induced expression of the complement component $\mathrm{C} 9$ gene in the grass carp Ctenopharyngodon idella. Veterinary Immunology and Immunopathology, 118, 270-282.

Muller, F., Zsolt, L., Laszio, V., Lazsio, M., \& Laszio, O. (1993). Efficient transient expression system based on square pulse electroporation and in vivo luciferase assay of fertilized fish eggs. Federation of European Biochemical Societies, 324(1), 27-32. 
Santoro, I.M., \& Walsh, K. (1991). Natural and synthetic DNA elements with the CArG motif differ in expression and protein-binding properties. Molecular and Cellular Biology, 11(12), 6296-6305.
Sin, F.Y.T. (1997). Transgenic fish. Reviews In Fish Biology And Fisheries, 7, 417-441. 